\title{
Conceptions of Brazilian Elementary and High School Students about Food Nutrients
}

\author{
Andréia de Freitas Zompero1, Helenara Regina Sampaio Figueiredo², \\ Tiago Henrique dos Santos Garbim², Karen Mayara Vieira ${ }^{2}$ \\ ${ }^{1}$ Universidade Estadual de Londrina e Universidade Pitágoras-Unopar, Londrina, Brazil \\ ${ }^{2}$ Universidade Pitágoras Unopar, Londrina, Brazil \\ Email: andzomp@yahoo.com.br
}

How to cite this paper: de Freitas Zompero, A., Figueiredo, H. R. S., dos Santos Garbim, T. H., \& Vieira, K. M. (2019). Conceptions of Brazilian Elementary and High School Students about Food Nutrients. Creative Education, 10, 862-873. https://doi.org/10.4236/ce.2019.105064

Received: April 3, 2019

Accepted: May 13, 2019

Published: May 16, 2019

Copyright $\odot 2019$ by author(s) and Scientific Research Publishing Inc. This work is licensed under the Creative Commons Attribution-NonCommercial International License (CC BY-NC 4.0). http://creativecommons.org/licenses/by-nc/4.0/

\begin{abstract}
The study was undertaken to investigate the conceptions of Brazilian Basic Education (Elementary and High School) Students about food nutrients, food pyramids, processed food labels and nutrition facts tables. The research involved groups from sixth to ninth grades of Elementary School and first to third grades of High School in a public school from Paraná State, Brazil. In this study, 257 students, aged $11-17$ years old, took part. For the identification of conceptions, group activities were performed using food pyramids, processed food labels and nutrition facts tables, aiming the analysis of their nutritional composition by students. Analysis showed students do not show satisfactory and coherent conceptions about food nutrients, and many students were not able to distinguish nutrients from food. In this sense, we highlight the need of Food Nutrition programs to endorse and include initiatives for students, regarding the positive comprehension of nutrients and their benefits to the body, besides healthy eating habits.
\end{abstract}

\section{Keywords}

Health, Nutritional Values, Food Nutrients Tables, Food Education, Teaching Process

\section{Introduction}

Food education takes part as an integral component on Brazilian curricular proposals. Educational documents emphasize knowledge regarding nutrition and eating habits based on Brazilian National Education Guidelines and Framework Law (Lei de Diretrizes e Bases da Educação-LDB) from 1996. Also, several documents present guidelines for teaching and learning issues, such as, 1997, 
1998 and 2002 versions of National Curriculum Parameters (Parâmetros Curriculares Nacionais); National Curriculum Guidelines (Orientações Curriculares) from 2006 and the current National Curriculum Guidelines for Basic Education (Diretrizes Curriculares Nacionais para Educação Básica).

Based on common diseases observed among young students as obesity, diabetes, dyslipidemia and hypertension, food education is shown to be a significant subject, as listed by Oliveira \& Fisberg (2003), genetic code and metabolism can influence in some cases; however, unhealthy eating habits and lifestyle, consisting on food and drinks high in fat and/or sugar, and the lack of physical exercise, are responsible for the increase of such diseases in this group.

As pointed out by Oliveira \& Luz (2008), World Health Organization (WHO) considers obesity and hypertension as current public health issues, tending to become a risk factor for fatal outcomes. According to the authors, industrial society has shaped the health status of population, influencing it negatively. Several studies have shown Brazil, like other developing countries, experiences a transition in nutrition, often determined by inappropriate eating habits. The issue has been a major challenge for public policy of the country (Coutinho et al., 2008).

Current researches highlight the importance of knowing and practicing healthy eating habits, since it is a smart choice that relies on behavior and lifestyle; then, population needs to be guided about the subject. Therefore, Triches \& Giugliani (2005) point out that, in order to promote healthy habits and reduce obesity levels, population must acquire knowledge and information on nutrition. In this sense, food education has its main objective encouraging people on their choices, ensuring healthy and enjoyable meals, and providing for physiological, psychological and social needs.

In Brazil, according to Law No. 11.947/2009 (Brasil, 2009), nutrition should be treated as a transversal theme, including food education along the teaching-learning process, going through the curriculum and addressing themes involving nutrition, healthy habits and lifestyle from food and nutrition security perspective. The Brazilian School Feeding Programme (PNAE) (Brasil, 2013), also endorses the need for inclusion of these subjects as a part of the curriculum approached in Elementary and High School levels, including healthy eating habits, food conservation and hygiene, among others.

According to Brazil's National Common Curricular Base (Brasil, 2017) for Early Childhood Education and Elementary Teaching, supported by Resolution CNE/CP n ${ }^{\circ} 2 / 2017$ based on CNE/CP n ${ }^{\circ}$ 15/2017, Food and Nutritional Education is a mandatory topic. Curriculums must include a transversal approach, including mandatory subjects that aim citizenship development.

The official document for High School Curriculum Parameters (Parâmetros Curriculares para o Ensino Médio) also includes subjects related to nutrition, emphasizing the relation between Science, Technology and Society. Therefore, discussions regarding food and nutrition issues include social problems as world hunger and transgenic products. 
Brazilian law 13.666/2018 approved on May 16th, 2018, includes Food and Nutritional Education in basic education. The authors involved in this law base the project on reduction of childhood obesity and healthy habits among students.

Much work still need to be done in order to promote food education at schools in an effective way. Studies show the conceptions of students about food nutrients lack in conceptual clarity; in addition, they have difficulties in distinguishing nutrients from food (Carvalho et al., 2012). In cases where the students can distinguish nutrients from food, the classification of nutrients is confusing. Recent researches on Brazilian Scientific Literacy (Garcia, 2014; Marins \& Jacob, 2015); show Brazilian people do not read or understand industrialized products labels or food nutrients tables. Bendino et al. (2012), emphasize the importance of educational campaigns, however, campaigns can have better results when the target audience already has some knowledge on the subject.

Based on the foregoing, this study aims to identify the conceptions of Brazilian Elementary and High School students about food nutrients and the understanding about food labels, food nutrients tables and food pyramids.

\section{Literature Review}

Many official curriculum documents set education in Brazil, and so is food education. Zompero et al. (2015) discuss the orientations of these documents, from Early Years Curriculum Guidelines (Referenciais Curriculares para Educação Infantil) to High School Curriculum Parameters (Parâmetros Curriculares para o Ensino Médio), concluding with the approach presented on the National Curriculum Guidelines for Basic Education (Diretrizes Curriculares Nacionais para Educação Básica) in Brazil.

The National Curriculum Guidelines for Basic Education (Diretrizes Curriculares Nacionais para Educação Básica) from 2013 reassert Law No. 11.947/2009 defined by Brazilian Environmental Education Policy (PNEA), including Food Education in scholar curriculum as a transversal theme, covering all the subjects in the curriculum.

Feeding programs in several countries from Latin America address food education, which, besides providing quality meals to students, also aims to promote their food and nutrition education through practices that involve the whole community. In Brazil, feeding programs also aim at food education for food consumption.

In 2012, FAO (Food and agriculture organization) national conference had "food and nutrition security: implications, impact and opportunities for Latin America and Caribbean" as its goal, including issues as scholar nutrition, food education and food waste. Thus, it can be noticed feeding programs concern about schools' food supply and food education, especially in Brazil.

Piperakis et al. (2004) propose the implementation of school feeding programs in Greece and other countries in Europe in order to improve the quality of eating habits, including fruits and vegetables on children's diet. Another objective 
of this project would be the opportunity of students to know the benefits of healthy food and habits. According to the authors, food education is part of scholar curriculum in Greece.

It is relevant to consider education must lead to the development of autonomous people, able to criticize and propose alternatives to their reality (Barbosa et al., 2013). As society is constantly changing, it is necessary to empower students to deal with social problems. Therefore, it is necessary to introduce them clear, stable, and critical thinking knowledge, preparing them for making decisions. Barbosa et al. (2013) emphasize the inclusion of food education in scholar curriculum, which can be developed by adding value to existing content, signifying life understanding, in addition to ethical, socio-anthropological and biological dimensions of their existence, eating and dwelling in the social space.

The authors above also emphasize the importance of understanding concepts that involve food and nutrition. In this respect, conceptual understanding is necessary to understand information from labels of processed food, nutrition facts tables, food pyramids, news and others. Science teaching considers this aspect as a part of what Scientific Literacy is, according to Sasseron \& Carvalho (2011). The authors classify three axes for Scientific Literacy, as the basic understanding of terms, concepts and fundamental scientific knowledge. Thus, the conceptual understanding is the foundation for food education.

Oliveira \& Luz (2008), state the construction of knowledge and its proper use by students depend on the content, the context in which it is used, the processes applied in its construction and the purposes of those who use it. Previous researches from the same authors show graduate students from public schools in Brazil present a complex conceptual profile, having conflicting views about nutrition and metabolism. Luz \& Poian (2005) discuss the incoherent concepts of nutrients and metabolism presented by students from undergraduate courses at UFRJ (Federal University of Rio de Janeiro), where the dominant conception is that glucose is the only source to ATP (Adenosine Triphosphate) production by cells, once these molecules store energy.

Studies from Piperakis et al. (2004), Oliveira \& Luz (2008), Carvalho et al. (2012), and Tamayo et al. (2013) also indicate several conceptions students have about nutrition and metabolism. Controversies found in these studies are, for example, between food and nutrients concepts or distinctions.

Prior conceptions regarding nutrients come from several means, such as TV, internet and social environment, allowing students to develop their explanations, scientifically or not. Many of the concepts are not scientific and need to be explored, as they are, in many cases, obstacles to learning processes (Tamayo et al., 2013). The same authors claim there is a lack of studies on the conceptions of students about food and nutrients.

A research from Enochson \& Redfors (2012), points out students aged 15-16 years old in Sweden had difficulties in the understanding of body systems and digestions, they also could not recognize the presence of protein in chicken meat. This study found students had more knowledge about vitamins than protein, 
concepts related to the frequent experiences involving vitamins in their daily life. Advertising of vitamin products and other nutritional supplements in Brazil, as in different parts of the world, have attributed many health benefits to vitamins, although they are not substantiated by science (Santos \& Barros Filho, 2002).

Santos \& Barros Filho (2002) conducted a study with first year students of undergraduate courses at a private university in São Paulo, Brazil. Some of the incoherent ideas from students regarded the relation between fatigue and stress to the lack of minerals and vitamins in the body; and the understanding of living in polluted environment and high levels of vitamins required. Some students also considered vitamin supplements could help smokers to maintain health safe; that people who practice physical activities need vitamin supplements to replace losses; and that vitamin $\mathrm{C}$ can prevent colds and flu. The authors suggest these questionable scientifically beliefs can be associated to the intake of these supplements.

Another research from Mann \& Treagust (2010), involving students aged 8 12 years old from Great Britain and Greece, shows students attribute the importance of carbohydrates and lipids to the human body, but are not able to distinguish the functions of such nutrients. In addition, the researchers have found students point out lipids are not good for health. The concepts observed may come from media presenting lipids to cause diseases.

Tamayo et al. (2013), allege prior knowledge have several features that are not easy to diagnose or modify, since it has a solid consistency for students. According to the authors, investigations that might reveal false myths and mistaken prior knowledge about food education are necessary.

Many authors emphasize the importance of knowledge students bring to the classroom in order to construct and reconstruct meanings (Santos, 1991; Ausubel et al., 2000; Campanário \& Otero, 2000). The progress of research on alternative conceptions occurred in the late 1970s, following the "movement of Alternative Conceptions". Studies from Cognitive Psychology state students learn subjects due to a personal construction process, although, the previous idea is a filter that allows students to understand the world and its conceptions (Campanário \& Otero, 2000).

As stated by Santos (1991), the conceptions brought from students are one of the most significant variables of science education, being the basis of learning issues. Therefore, exploring the concepts of students in different contents can bring important contributions to teaching processes, allowing teachers to meet different points of view about certain content and so conduct educational activities effectively.

\section{Methodology}

The study was conducted at a public school located in the state of Paraná, Brazil. Students from Basic Education took part in the study, where different subjects related to food education are ministered throughout the education level. The final data set contained return from 257 students, aged 11 - 17 years old. 
Groups of four students from the same grades were organized; each group received a set containing a food pyramid and four nutrition facts tables indicating the nutritional values of different food, which were identified as A, B, C and D. The Brazilian Food Composition Table (TACO) and the University of Campinas (UNICAMP) developed the four nutrition facts tables interpreted by students. Coding was applied in order to not interfere in the answers. From the analysis of the set provided, the students had to answer the following questions:

1) Which nutrients can you find in each level of the food pyramid?

2) Analyze nutrition tables $A$ and $B$. Which vitamins and minerals can you find in each one?

3) Analyze nutrition tables A, B, C and D. Point out two of them a person who wants to lose weight should avoid. How do you figure that out?

The food pyramid analyzed by students presented pictures of each food level. In level 1, pasta, bread and cereals, represented carbohydrates. In level 2, fruits and vegetables, indicated the presence of vitamins and minerals on it. In level 3, meat, fish, poultry, milk, yogurt and cheese, represented protein and in level 4, fats, oils and sweets, indicated the presence of lipids on it.

\section{Results and Discussion}

In the first question, the groups of students had to point which nutrients they could find in each level of the food pyramid provided, however, many students identified not only nutrients, but also different examples of food (Figure 1). Based on the number of students per grade (from 6th grade of Elementary School to 3rd grade of High School), it was checked how many students listed names of food and how many referred to the nutrient, for example, some students answered "meat" when asked about an example of nutrient. Given the number of responses, the average percentage of indications in each class was taken, according to the chart.

According to the analysis, $46 \%$ of Elementary School students mentioned names of nutrients and 54\% names of food. For High School students, 93\% named nutrients and 7\% names of food from the food pyramid, such as: pasta, cake, meat, fish, etc. The data is compatible with other studies cited above, in which students are not able to distinguish food from nutrients.

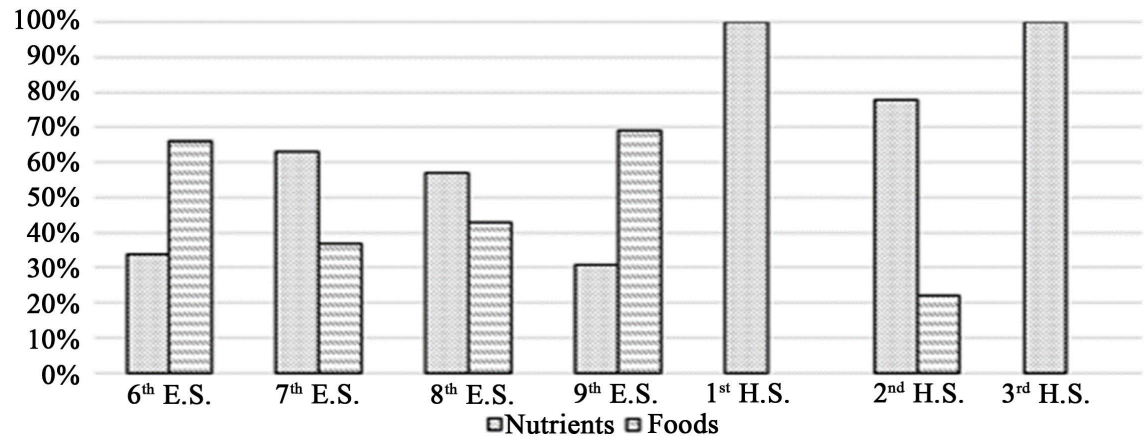

Figure 1. Averages for concepts on nutrients and food (Question 1). 
It was possible to observe Elementary School students presented more difficulties in mentioning nutrients when compared to High School students. Furthermore, in sixth and ninth grades groups there was an expressive low performance in distinguishing nutrients from food. Based on the results, we judged necessary to find if the nutrients listed by the groups agreed with those presented in each of the food pyramid levels. In Figure 2 the averages percentages for each nutrient listed by the groups are presented.

In level 1 , the nutrients listed by students were carbohydrates and iron. We observe almost $80 \%$ of High School students from the first grade pointed these nutrients, by contrast, Elementary School students listed names of food from the pyramid, for example, bread and pasta.

In level 2, the most listed nutrients were vitamins and minerals. Students also listed names of food from this level, as they did before. However, we observed $62 \%$ of students listed vitamins, as this is the most indicated nutrient. The data is compatible with Enochson \& Redfors (2012) studies, where students refer to vitamins as their first option when they have to name nutrients.

In level 3, the most listed nutrients were proteins, vitamins and minerals. Yet in this level, according to the food pyramid provided, proteins are predominant, not the vitamins. It is possible to notice again associations of vitamins with some types of food.

In level 4, the most listed nutrients were lipids, sugars and some vitamins. It is important to highlight vitamins are not part of this level. High School students from the first grade indicated the right nutrients from this level, showing $30 \%$ of right answers, the highest average for this question when compared to the other groups. Once again, we noticed some difficulties on distinguishing food from nutrients, since some students listed olive oil or pie, but not the expected nutrients.

According to the results, High School students from the first grade presented the best performance when analyzing the food pyramid, once they listed the correct nutrients found in each level. The students from this grade learned concepts about organic and inorganic compounds of cells in Biology one month food nutrients to the cell compounds previously studied in their regular subject at school.

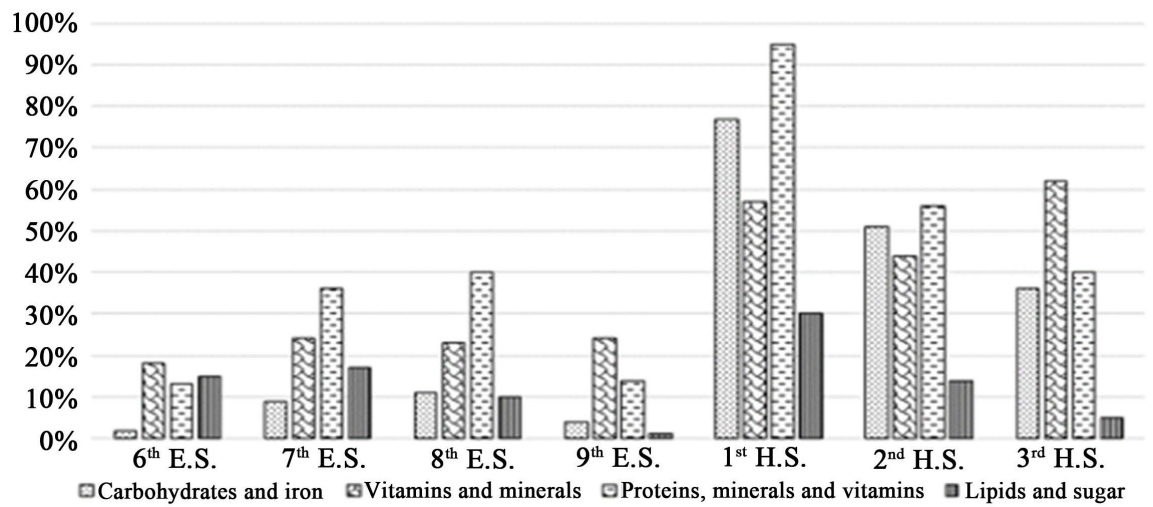

Figure 2. Averages for nutrients listed in the food pyramid levels (Question 1). 
before the activities here reported. Probably, they found it easier to associate

In the second question, Elementary School students gave no very correct answers. By analyzing the answers, we can infer these students cannot distinguish vitamins and minerals, listing proteins or carbohydrates instead, or also putting vitamins and minerals together when analyzing nutrition facts tables $\mathrm{A}$ and $\mathrm{B}$. In High School groups from the second and third grade, 55\% listed vitamins and minerals correctly for each nutrition facts table, A and B.

For a better understanding of these conceptions, we analyzed which vitamins and minerals were the most listed in each group, not taking into consideration if another nutrient appeared in the answers. In Figure 3, we present in percent numbers for right and wrong identifications of vitamins in nutrition facts tables $A$ and $B$

Students who made mistakes pointed calcium, zinc and carbohydrates as vitamins with higher frequencies; however, some answers also included fibers, phosphorus and sodium. Among vitamin C, vitamin B2 and vitamin B6, found in nutrition facts tables $\mathrm{A}$ and $\mathrm{B}$, the most listed was vitamin $\mathrm{C}$. We relate this result to the facts presented by Enochson \& Redfors (2012), since the authors relate social aspects to vitamins, emphasizing how media can disclosure information related to the benefits of vitamins; in addition, according to Santos \& Barros Filho (2002), people relate vitamin C to the prevention of cold and flu.

Data shows only $35 \%$ of students answered the questions correctly, listing the names of vitamins and distinguishing them from minerals. Conversely, $65 \%$ of students made mistakes when answering these questions, this average also includes students who could not establish a difference between minerals and vitamins. Comparing the results to the answers given in the first question, we conclude students can relate vitamins to fruits and vegetables easily, what is not observed when they have to distinguish vitamins from nutrients in a nutrition facts table. It allows us to infer how limited are their conceptions about nutrients. In Figure 4, we present the percentages of right and wrong identifications of minerals in nutrition facts tables A and B.

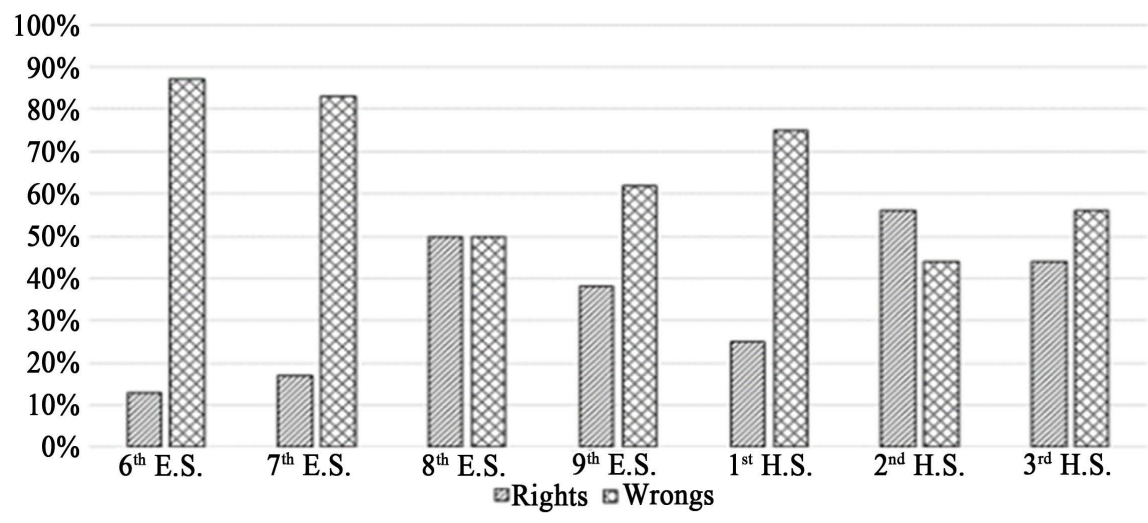

Figure 3. Percentages of right and wrong identifications of vitamins in nutrition facts tables (Question 2). 


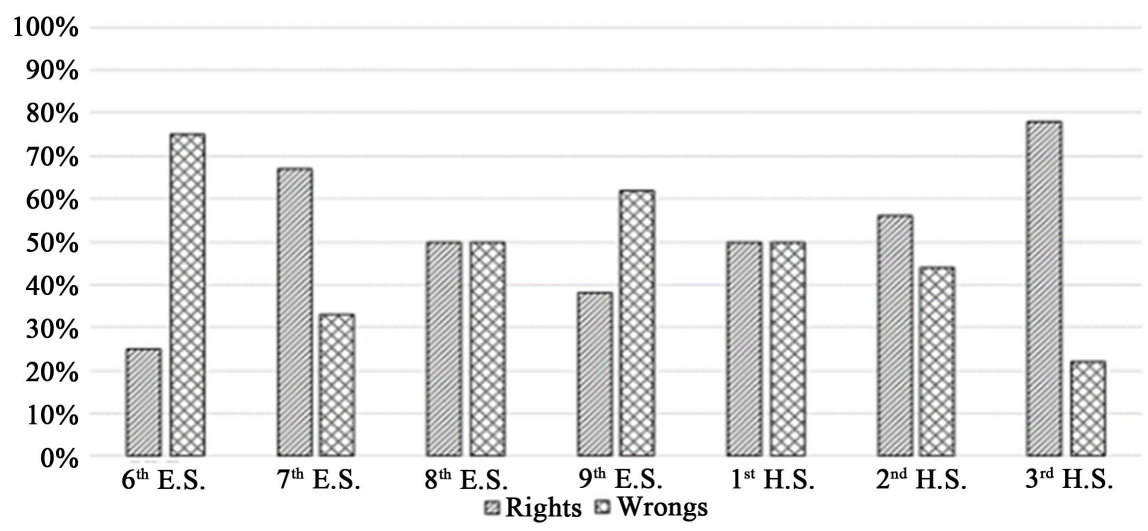

Figure 4. Percentages of right and wrong identifications of minerals in nutrition facts tables (Question 2).

Comparing the process of identifying minerals to the one identifying vitamins, we can notice by Figure 3 and Figure 4 that students had a better performance when they had to identify minerals. However, according to Figure 4, students tend to make mistakes when relating minerals to other nutrients, for an example, the most listed as minerals were lipids, carbohydrates and proteins. A group from the sixth grade (Elementary School) listed fruits and vegetables instead of minerals or vitamins, but the other students were able to distinguish, in this question, food from nutrients, listing vitamins and minerals as expected from them. The most listed in every group was calcium, showing how students can recognize this mineral easily. For the second question, 52\% of students listed minerals correctly, and $48 \%$ related minerals to other nutrients incorrectly. In Figure 5 we present percentages of the indications right and wrong identifications of the highest in calories nutrition facts tables (C and D).

In the third question, students had to identify which nutrition facts tables were the highest in calories. From the set analyzed by students, nutrition facts tables $\mathrm{C}$ and D presented the higher amounts of calories and fats when compared to the others. The average of correct answers in general was $56 \%$; however, students listed the correct tables, but were not able to justify their choices. We expected a better performance in this question by the fact population knows how high in calories food are related to weight gain, however data shows students were not able to make these relations. Some students related minerals and vitamins to weight gain, while some just listed different food, as bread, milk and meat, and others just listed options from the tables, such as fats and sodium. Our data is compatible with Mann \& Treagust (2010) studies that involved student from ages between 13 - 17 years old; these students could not relate the presence of lipids in food or energy release, a very similar situation found in this study.

We consider worrisome the fact of students not understanding clearly how food components can cause weight gain. Researches regarding obesity from 2015 show half of Brazilian population is overweight, what is developed by the age of 18. In this sense, we highlight the importance for recognition of the nutritional 


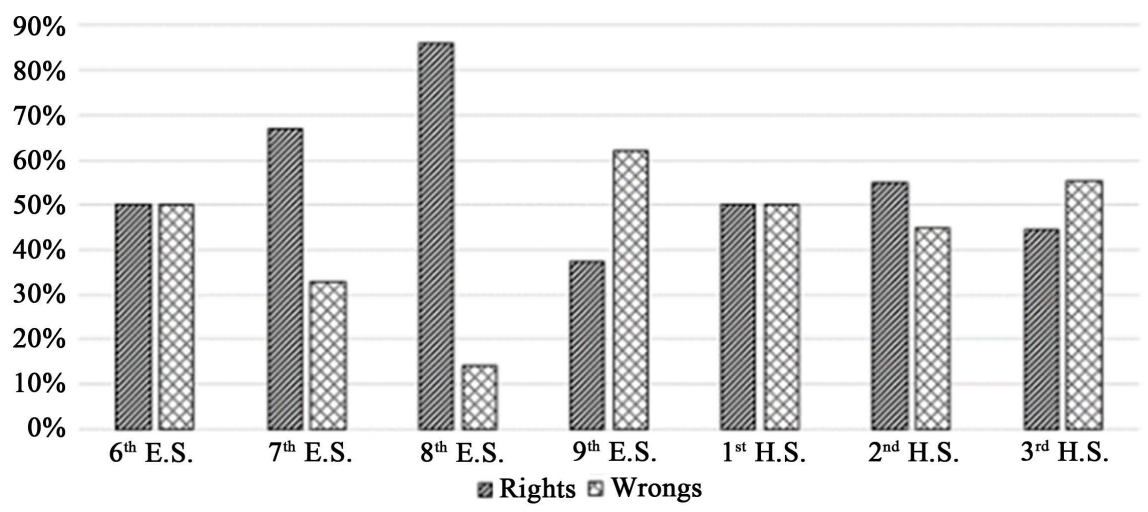

Figure 5. Percentages of the indications of the highest in calories nutrition facts tables (Question 3).

value for common food from our students, also what the functions of nutrients in the human body are, in order to make healthy food choices.

\section{Conclusion}

Prior knowledge brought by students has a great influence in the teaching-learning process, so it is extremely important for the teacher to know what students already know about any topic; in this way teachers are able to propose activities that favor meaningful learning. Official curricular documents propose food education in Brazil in order to provide students an education that can aware them about the benefits of balanced diets for health.

The results of this study are worrisome, although media is constantly disclosing information on how important healthy habits are; we notice Brazilian students have no clear knowledge about food nutrients and sometimes cannot distinguish nutrients from common food.

Results bring significant outcomes on the understanding students which show about nutritional composition, food labels and food nutrients tables as well. Based on the overall, we can infer campaigns and education projects that aim at healthy habits which may not have an effective impact on students, considering their prior knowledge on the subject.

We agree with Barbosa et al. (2013) that education must lead citizens to autonomy and making decisions efficiently. However, it is necessary to understand the importance of establishing significant conceptual basis in order to learn properly before opining. According to Tamayo et al. (2013), we recognize the importance of investigations that might reveal false myths and mistaken prior knowledge about Food Education. Generally, researches emphasize diet habits of population, not giving proper attention to the concepts they have about food compounds. On this subject, this study contributes to academy by presenting conceptions Brazilian students have regarding food nutrients, also comparing them to the conceptions of students from other countries and pointing what is convergent or not. 


\section{Conflicts of Interest}

The authors declare no conflicts of interest regarding the publication of this paper.

\section{References}

Ausubel, D., Novak, J., \& Hanesian, H. (2000). Aquisição e retenção de conhecimentos: uma perspectiva cognitiva. Lisboa: Plátano.

Barbosa, N. V. S., Machado, N. M. V., Soares, M. C. V., \& Pinto, A. R. R. (2013). Alimentação na escola e autonomia-Desafios e possibilidades. Ciência \& Saúde Coletiva, 4, 937-945. https://doi.org/10.1590/S1413-81232013000400005

Bendino, N. I., Popolim, W. D., \& Oliveira, R. C. (2012). Avaliação do conhecimento e dificuldades de consumidores frequentadores de supermercado convencional em relação à rotulagem de alimentos e informação nutricional. Journal of the Health Sciences Institute, 3, 261-265.

Brasil (2009). Presidência da República. Lei $\mathrm{n}^{\circ} 11.947$, de 16 de junho de 2009. Dispóe sobre o atendimento da alimentação escolar e do Programa Dinheiro Direto na Escola aos alunos da educação básica; altera as Leis nos 10.880, de 9 de junho de 2004, 11.273, de 6 de fevereiro de 2006, 11.507, de 20 de julho de 2007; revoga dispositivos da Medida Provisória n o 2.178-36, de 24 de agosto de 2001, e a Lei no 8.913, de 12 de julho de 1994; e dá outras providências. Brasília: DOU, 17 Jun. 2009.

Brasil (2013). Ministério da Educação. Fundo Nacional de Desenvolvimento da Educação. Resolução $n^{\circ} 26$ de 17 de junho de 2013. Dispõe sobre o atendimento da alimentação escolar aos alunos da educação básica no âmbito do programa de alimentação escolar-PNAE. Brasília: DOU, 18 Jun. 2013.

Brasil (2017). Ministério da Educação. Secretaria da Educação Básica. Base Nacional Comum Curricular. Brasília, DF.

Campanário, J. M., \& Otero, J. C. (2000). Más allá de las ideas previas como dificultades de aprendizaje: Las pautas de pensamiento, las concepciones epistemológicas y las estrategias metacognitivas de los alumnos de ciencias. Enseñanza de las ciências, 2, 155-169.

Carvalho, J. C. Q., Couto, S. G., \& Bossolan, N. R, S. (2012). Algumas concepções de alunos do Ensino Médio a respeito das proteínas. Ciência \& Educação, 18, 897-912. https://doi.org/10.1590/S1516-73132012000400010

Coutinho, J. G., Gentil, P. C., \& Toral, N. (2008). A desnutrição e obesidade no Brasil: o enfrentamento com base na agenda única da nutrição. Cadernos de Saúde Pública, 24, S332-S340. https://doi.org/10.1590/S0102-311X2008001400018

Enochson, P. G., \& Redfors, A. (2012). Students' Ideas about the Human Body and Their Ability to Transfer Knowledge between Related Scenarios. European Journal of Health and Biology Education, 1, 3-29. https://doi.org/10.20897/lectito.201202

Garcia, M. (2014). Brasileiro: “analfabeto” científico? Instituto Ciência Hoje. http://cienciahoje.org.br/brasileiro-analfabeto-cientifico/

Luz, M. R. M. P., \& Poian, A. T. (2005). O ensino classificatório do metabolismo humano. Ciência e Cultura, 4, 43-45.

Mann, M., \& Treagust, D. F. (2010). Students' Conceptions about Energy and the Human Body. Science Education International, 3, 144-159.

Marins, B. R., \& Jacob, S. C. (2015). Avaliação do hábito de leitura e da compreensão da rotulagem por consumidores de Niterói, Rio de Janeiro. Revista Visa em debate: 
sociedade, ciência e tecnologia, 3, 122-129.

Oliveira, C. L. de., \& Fisberg, M. (2003). Obesidade na infância e adolescência-Uma verdadeira epidemia. Arquivos Brasileiros de Endocrinologia e Metabologia, 47, 107-108. https://doi.org/10.1590/S0004-27302003000200001

Oliveira, M. F. A., \& Luz, M. R. M. P. (2008). Identificando os nutrientes energéticos: uma abordagem baseada em ensino investigativo para alunos do ensino fundamental. Revista Brasileira de Pesquisa em Educação em Ciências, 2, 1-19.

Piperakis, S. M., Soutiriou, A., Georgiou, E., Thanou, A., \& Zafiropoulou, M. (2004). Understanding Nutrition: A Study of Greek Primary School Children Dietary Habits, before and after Classroom Nutrition Intervention. Journal of Science Education and Technology, 13, 129-136. https://doi.org/10.1023/B:JOST.0000019645.03448.65

Santos, K. M. O., \& Barros Filho, A. A. (2002). Consumo de produtos vitamínicos entre universitários de São Paulo. Revista de Saúde Pública, 36, 250-253. https://doi.org/10.1590/S0034-89102002000200021

Santos, M. E. V. M. (1991). Mudança Conceitual na Sala de Aula: Um desafio pedagógico. Livros Horizonte: Lisboa.

Sasseron, L. H., \& Carvalho, A. M. P. (2011). Alfabetização Científica: uma revisão bibliográfica. Investigações em Ensino de Ciências, 1, 59-77.

Tamayo, A. P., Juánez, J. C., \& Macias, C. R. (2013). Conocimientos prévios em alimentación y nutrición y su relación com el índice de massa corporal de un grupo de estudiantes de un centro penitenciário español; un recurso em educación para la salud. Ensayos, Revista de la Facultad de Educación de Albacete, 28, 87-100.

Triches, R. M., \& Giugliani, E. R. J. (2005). Obesidade, práticas alimentares e conhecimentos de nutrição em escolares. Revista de Saúde Pública, 4, 541-547. https://doi.org/10.1590/S0034-89102005000400004

Zompero, A. F., Suzuki, R. M., Laburú, C. E., \& Frasson, F. (2015). A Educação Alimentar nos documentos de ensino para Educação Básica. Revista Ciências \& Ideias, 2, 71-82. 